\title{
NATURAL HAZARDS \\ on the Island of Hawaii
}

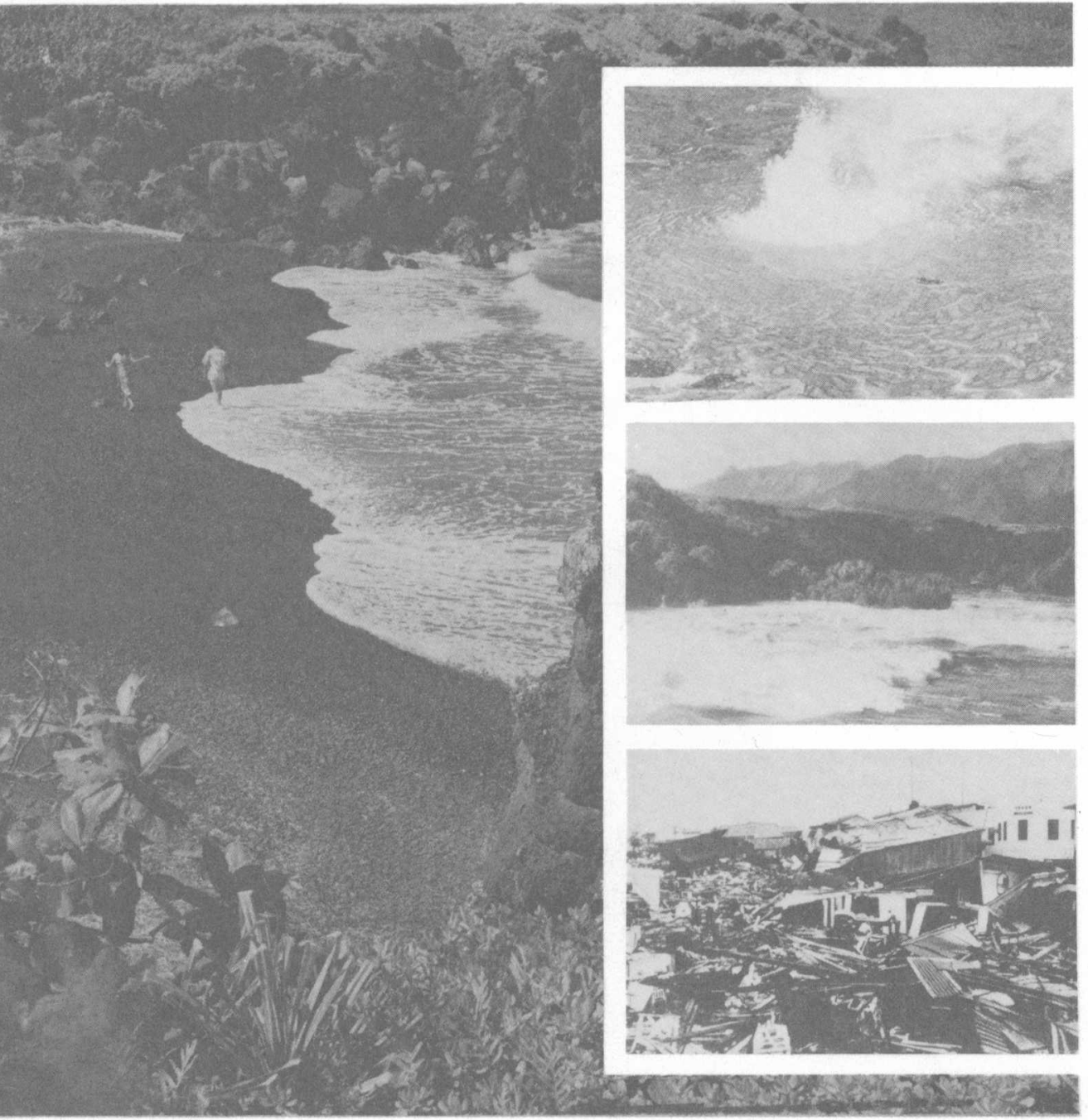

United States Department of the Interior/Geological Survey 


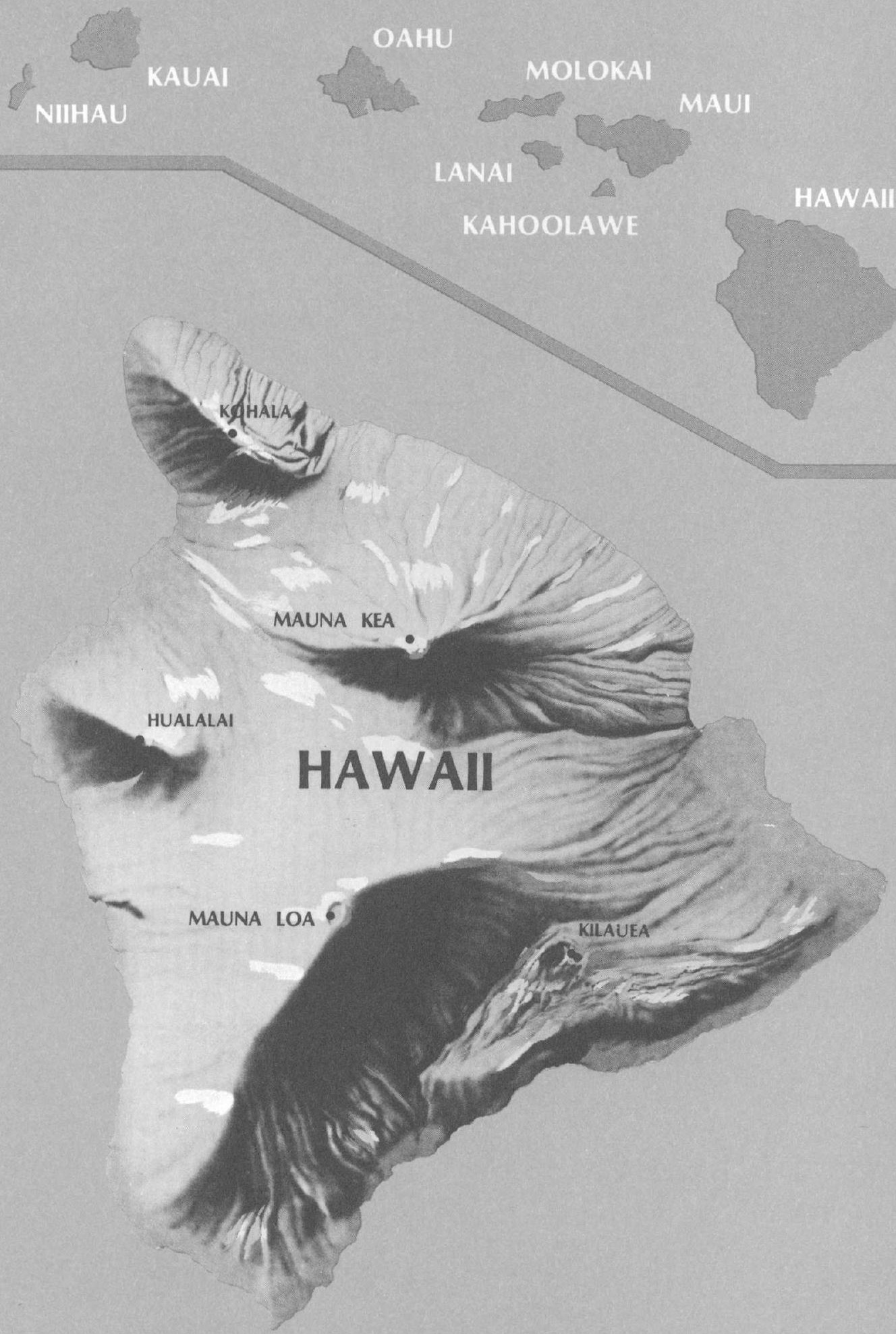




\section{NATURAL HAZARDS}

\section{on the Island of Hawaii}

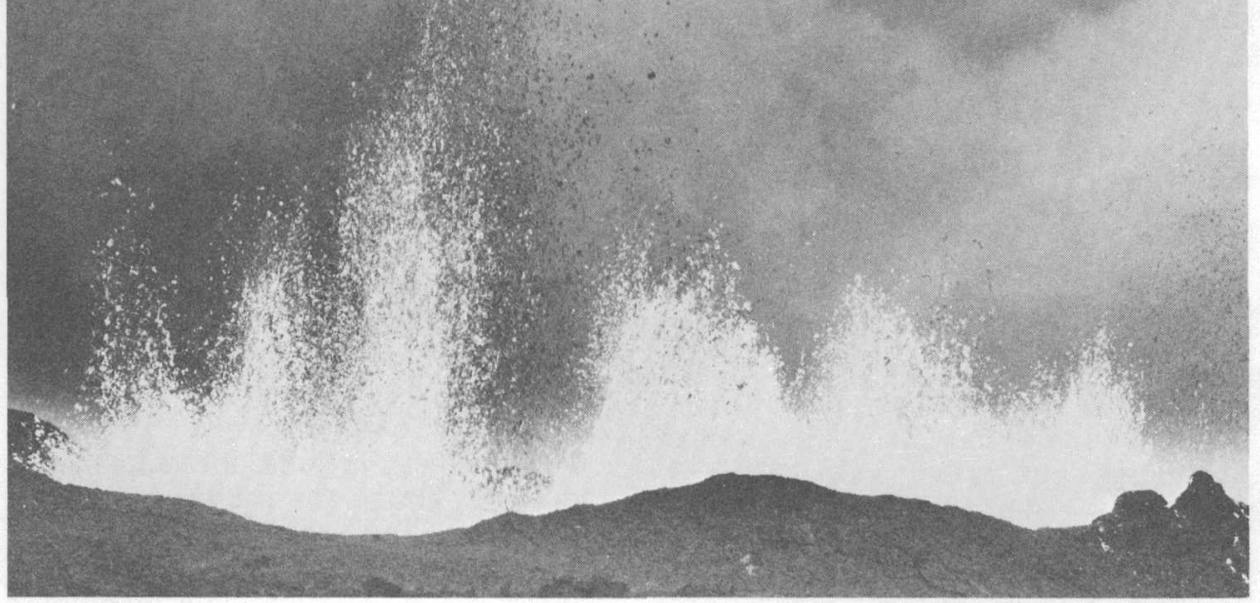

$\mathbf{T}$ he island of Hawaii and the other islands of the Hawaiian chain are products of volcanic eruptions. Lava flows from hundreds of thousands of eruptions through countless centuries have built the Hawaiian Islands. Some volcanoes on the island of Hawaii have been very active during historic time, and similar activity is expected to continue throughout the foreseeable future.

Volcanoes have always been an important element in the lives of Hawaii's inhabitants. Volcanic rocks are the raw materials from which the rich soils are derived that are the basis of Hawaii's largest industry-agriculture. Tourism, the island's second largest industry, also benefits from the volcanoes; the eruptions provide unsurpassed spectacles that attract visitors.

Hawaiian volcanic activity, however, as well as other natural events such as earthquakes and tsunamis (earthquaketriggered sea waves), can be hazardous to people and property. Even though no place on Earth is immune from some sort of natural hazard, the island of Hawaii has its own individual blend. But when the hazards are clearly recognized, careful planning can minimize any possible disturbance and damage. The benefits of living, working, and visiting in $\mathrm{Ha}$ - waii are well known. They can be enhanced by recognizing and realistically considering the existing hazards.

This booklet discusses some common questions about some natural hazards on the island of Hawaii. The replies are brief and generalized; further information may be obtained from one or more of the references listed at the end of this booklet.

\section{How great are the hazards from Ha- waii's volcanoes?}

The hazards are severe enough to have caused property losses on certain parts of the island throughout Hawaiian recorded history. The village of Hoopuloa on Mauna Loa's west flank was buried by a lava flow in 1926. Much property in the Puna District was destroyed by flows in 1955, and even more property, including the village of $\mathrm{Ka}$ poho, was destroyed by flows in 1960 . In spite of such losses, most areas on the island have been free of damage. Thus, it is crucial to identify the hazardous areas to avoid losses without overreacting to danger. Generally there is very little direct danger to human life, but the risk to property is great enough that volcanic hazards should be considered in all plans for land use-even 
though such consideration for many places will quickly determine that the risk is low.

Hawaii has been inhabited for perhaps a thousand years, and people have lived successfully beside and on the active volcanoes. The early Hawaiians quickly learned, however, to adjust their lives to the threat of volcanic activity. They either avoided certain areas or entered them briefly with awe and respect. Even so, their activities were sometimes abruptly curtailed by lava flows and other effects of volcanic activity. Recent residents of Hawaii have had similar experiences. They, too, recognize that certain areas are particularly susceptible to volcanic disturbances. Many of these areas have never been inhabited, but as the population increases, the desire to move into previously little used or unused land increases. Under the pressures of a growing population and expanding economyespecially during prolonged lulls in volcanic activity - the potential hazards tend to be forgotten or underestimated.

\section{What kinds of hazards do the vol- canoes present?}

Lava flows are the most common volcanic hazard in Hawaii. Other hazards include lava spatter, corrosive volcanic gases, ash particles and-rarely-explosions of turbulent c!ouds of gas that may carry dust, rock fragments, and large blocks. Related hazards are ground shifts that cause unequal settling, fractures that break the Earth's surface, and earthquake shaking.

\section{How may volcanic events endanger people?}

Eruptions may endanger people's property, livelihood, and peace of mind, but seldom their lives. The vast majority of Hawaiian eruptions are gentle; the lava moves slowly, and warnings of impending eruptions allow people to reach places of safety. No human lives have been lost to lava flows during the 19th and 20th centuries.

Explosive eruptions are rare in $\mathrm{Ha}$ waii, but they are potentially lethal. A gas-cloud eruption about 1790, in a normally uninhabited area, killed many members of a traveling Hawaiian army. Another explosive eruption in 1924 threw large blocks of rock into the air and claimed the life of a spectator who failed to heed warnings to leave. But the overall threat to life by explosive eruptions is relatively low, both because of their infrequency and because of warnings.

\section{How may volcanic events endanger property?}

The principal effect is the burial of land and the works of man by flowing lava. Less commonly, property may be blanketed by falling spatter from fountains or by ash and larger fragments expelled by rare explosive eruptions. Other effects include the damage to buildings and roads caused by ground cracking, corrosion of materials by volcanic gases, fires started by lava, and abrasion of plants and goods by erupted particles. Risks to property are high compared with risks to life, simply because land and buildings cannot be moved from the path of an advancing flow or other destructive agent. Destruction of the works of man and agricultural soils by a flow of lava can be complete, whereas damage from particles and gases is generally less serious. Reduction of such risks is possible when the hazards are understood well enough to predict-at least in a general way-what areas are most likely to be affected and how often.

\section{Should vulnerable areas be aban- doned?}

No. For each area, however, the risks should be compared with the potential gains from developing and using the land. Even in areas of relatively high risk, certain types of land use may be appropriate. Many other factors must be considered by planners and local government officials in deciding how land can best serve the needs of the people. Nevertheless, sensible decisions on land use can best be reached with full awareness and adequate knowledge of the nature and degree of natural hazards. If the hazards are ignored, the results can range from inconvenience to catastrophe. 


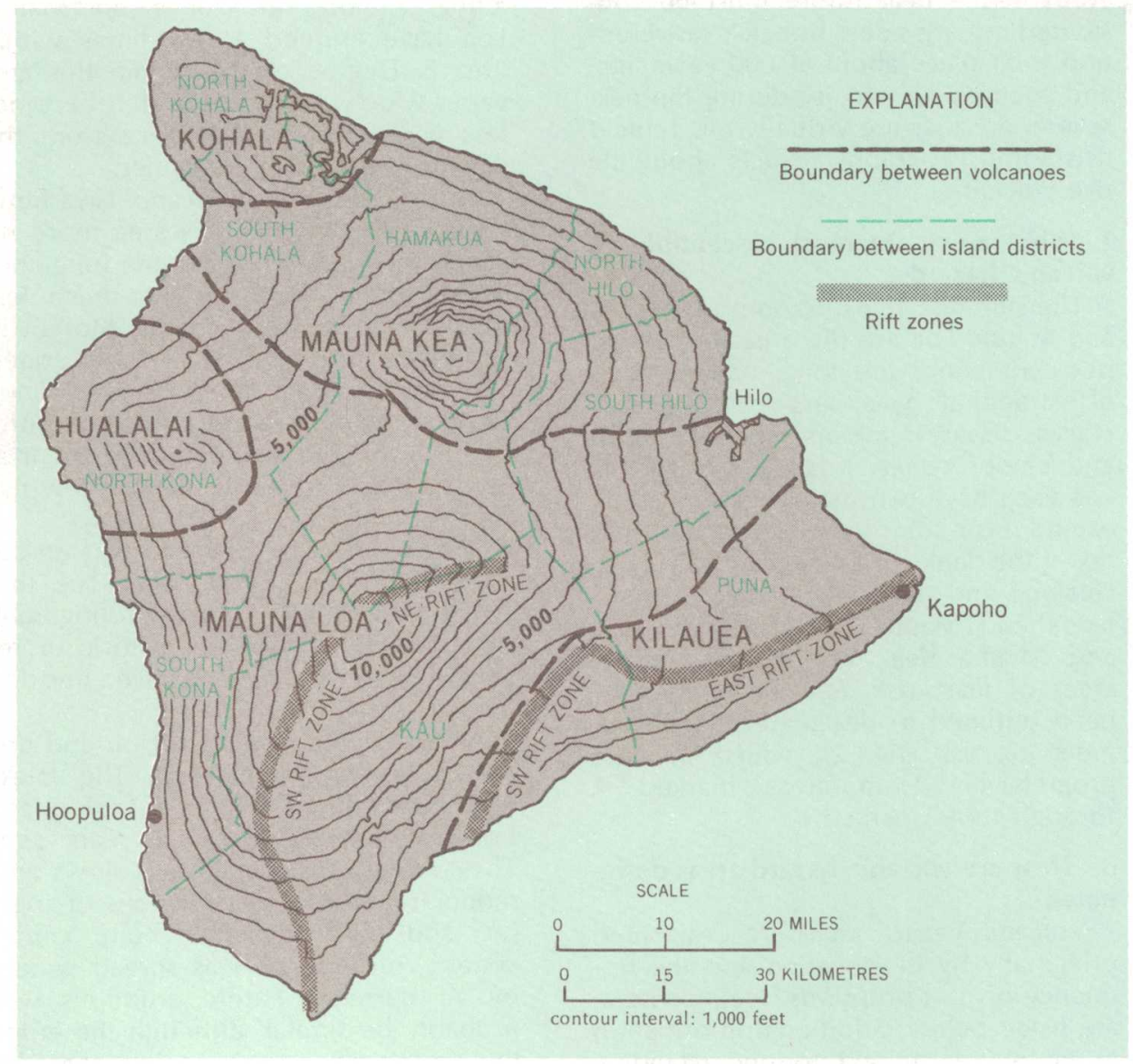

Figure 1.--Index map of the island of Hawaii.

\section{Can eruptions occur anywhere on the island?}

Probably not. Only two of the island's five volcanoes, Kilauea and Mauna Loa (fig. 1) have erupted often during the 19th and 20th centuries. The location and frequency of past eruptions are the best clues as to where new eruptions are likely to occur, and the present behavior of Mauna Loa and Kilauea in- dicates that they will be the source of most of Hawaii's future eruptions.

Hualalai Volcano last erupted about 1800 , and will probably erupt again, but its history suggests that future eruptions are not likely to be frequent. Mauna Kea last erupted between 3,000 and 5,000 years ago and might possibly erupt again. But the probability that it will

Table 1.-Physical dimensions of the parts of Hawaii's volcanoes (fig. 1) that are above sea level.

\begin{tabular}{|c|c|c|c|c|c|}
\hline \multirow{3}{*}{ Volcano } & \multirow{2}{*}{\multicolumn{2}{|c|}{$\begin{array}{c}\text { Elevation of } \\
\text { highest point }\end{array}$}} & \multicolumn{2}{|c|}{ Area } & \multirow{3}{*}{$\begin{array}{l}\text { Percent } \\
\text { of area of } \\
\text { island }\end{array}$} \\
\hline & & & Square & Square & \\
\hline & Feet & Metres & miles & kilometres & \\
\hline Mauna Loa. & 13,677 & 4,169 & 2,035 & 5,271 & 50.5 \\
\hline Kilauea ........ & 4,090 & 1,247 & 552 & 1,430 & 13.7 \\
\hline Hualalai $\ldots . \ldots \ldots$. & 8,271 & 2,521 & 290 & 751 & 7.2 \\
\hline Mauna Kea ......... & 13,796 & 4,205 & 919 & 2,380 & 22.8 \\
\hline Kohala $\ldots \ldots \ldots \ldots$ & 5,480 & 1,670 & 234 & 606 & 5.8 \\
\hline Total island $\ldots . \ldots \ldots$ & - & - & 4,030 & 10,438 & 100 \\
\hline
\end{tabular}


erupt in the near future must be considered as very small. Kohala's last eruption took place about 60,000 years ago, and chances for activity during the next several decades are virtually nil. Table 1 lists some geographical facts about the five volcanoes.

\section{What areas are most susceptible to volcanic hazards?}

The summits and rift zones of Kilauea and Mauna Loa are the areas of highest risk. Rift zones are long, narrow belts of structural weakness that include cracks, fissures, craters, spatter cones, and cinder cones. Kilauea and Mauna Loa each have two major rift zones that extend from the summit to points far down the flanks of the volcanoes (fig. 1). Hualalai and parts of the flanks of Kilauea and Mauna Loa have less risk, and Mauna Kea and Kohala are the areas of least risk. Specific areas have been outlined to designate relative degrees of risk (fig. 2), which increase progressively from areas marked $A$ through those marked $F$.

\section{How are volcanic hazard areas desig- nated?}

Volcanic hazard areas are designated principally by the location and the frequency of past eruptions. Major criteria are listed below; additional information in table 2 is an aid to understanding the relative degree of hazard within each of the areas.

Area $F$, the area of highest risk, includes the summit areas and major rift zones of Kilauea and Mauna Loa. Most of the land labeled $F$ has a historic and recent prehistoric record of active volcanic vents, cones, and craters; ground cracking and subsidence; and burial by lava flows. Narrow coastal regions on parts of Kilauea and Mauna Loa are also labeled $F$ because they lie within belts of frequently active faults in which the land is subject to cracking, abrupt subsidence, and possible flooding by locally generated tsunamis.

Area $\mathbf{E}$ includes the flanks of Kilauea and Mauna Loa that lie directly downslope from the summit areas and rift zones where lava flows originate. Land labeled $E$ is susceptible to burial by lava flows erupted within the summit and rift areas labeled $F$. In addition, vents along minor rift zones on Mauna Loa have erupted a few times within area E. Degree of risk within this area varies widely, but in general, it becomes less with increasing distance from the summits and major rift zones.

Area DE, Hualalai Volcano. Lava flows have buried land in this area more recently than in area D. Yet the frequency of eruptions of Hualalai is much less than Kilauea and Mauna Loa. Moreover, vents are not confined to rift zones. Risk on Hualalai is rather poorly defined because of the sparse historic record, but it probably spans a range equivalent to those in area $D$ and the low risk parts of area $E$.

Area D includes selected areas on the flanks of Kilauea and Mauna Loa that are somewhat protected by topography from burial by lava. No historic or recent prehistoric flows have invaded these areas.

Area $\mathbf{C}$ is the summit region and upper flanks of Mauna Kea. The latest eruptions within this area took place between 3,000 and 5,000 years ago. They consisted of small lava flows and moderately explosive emissions of spatter and particles that built cinder cones. Volcanic ash was spread widely by air currents. Future eruptions will probably be similar, although the eruptive frequency is now so low that the hazard must be regarded as very small.

Area $\mathbf{B}$ consists of the lower flanks of Mauna Kea. No eruptions have occurred in this area during the last 10,000 years. This land could be buried only by relatively long lava flows issuing from vents in area $C$.

Area A, Kohala Volcano. No volcanic activity has occurred in this area for about 60,000 years.

\section{How dangerous are the areas of high hazards?}

A careful study of figure 2 and table 2 and their implications is perhaps the best way to answer this question. For example, since about 1800 A.D., lava flows from 35 different eruptions have covered parts of area $E$; only one eruption on the north flank of Mauna Loa, in 1859 , originated within area E. About 15 percent of area $E$ has been covered by lava during this 175 -year period. In 


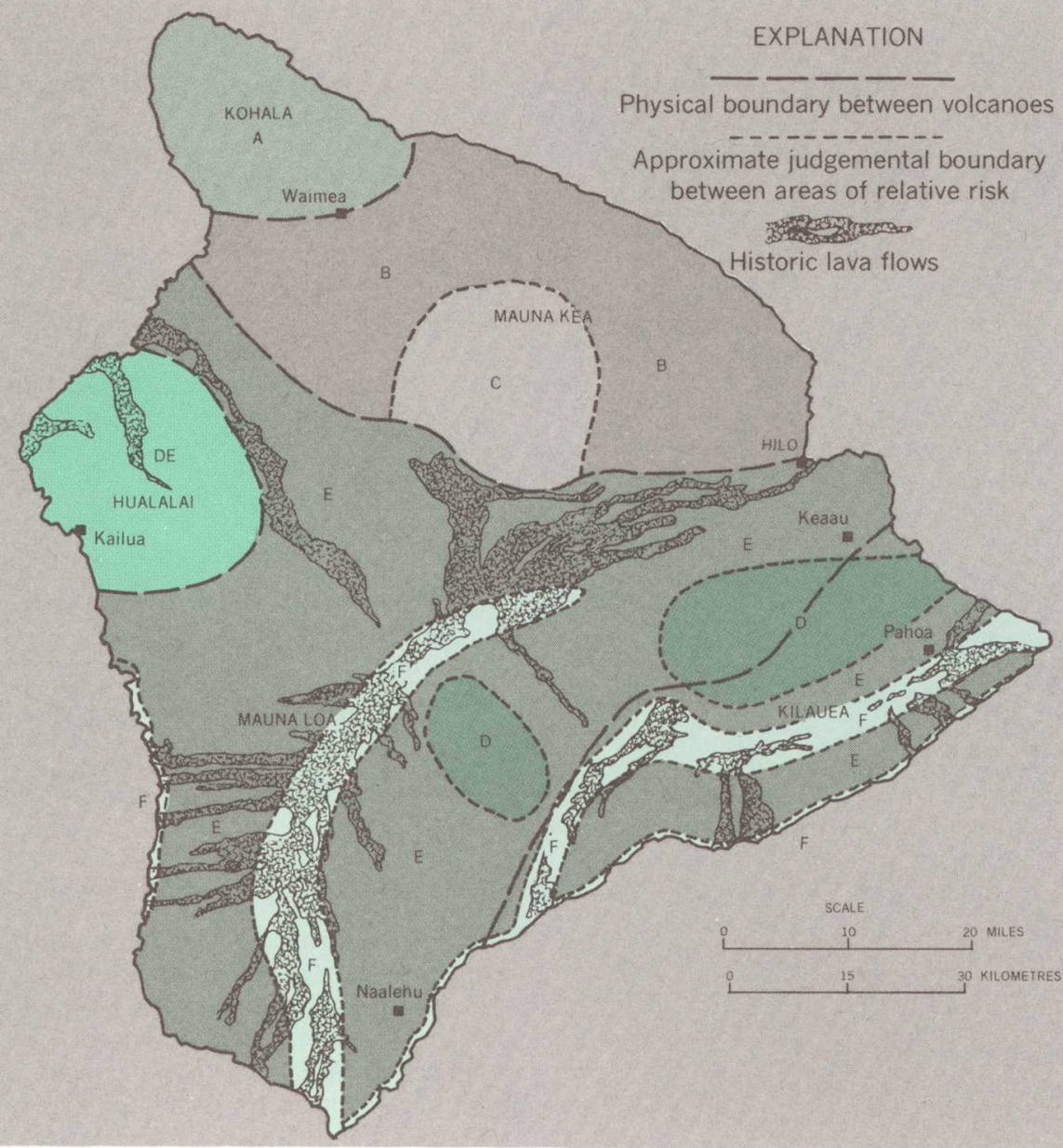

Figure 2.-Areas of relative risk from volcanic hazards. Risk increases from " $A$ " through " $F$ ". Map shows lava flows erupted between the years 1800 and 1974.

Table 2.-Number of eruptions originating within hazard areas and number of times lava flows have covered land within hazard areas during historic and recent prehistoric time.

\begin{tabular}{|c|c|c|c|c|c|c|}
\hline \multicolumn{4}{|c|}{$\begin{array}{l}\text { Historic time (since } \\
\text { approximately } 1800 \text { ) }\end{array}$} & \multicolumn{3}{|c|}{$\begin{array}{c}\text { Recent prehistoric time } \\
(5,000 \text {-year interval } \\
\text { prior to } 1800)\end{array}$} \\
\hline Area & $\begin{array}{l}\text { Number of } \\
\text { times vents } \\
\text { have erupted } \\
\text { within area }\end{array}$ & $\begin{array}{l}\text { Number of times } \\
\text { lava flows have } \\
\text { covered land } \\
\text { within area }\end{array}$ & $\begin{array}{l}\text { Percentage } \\
\text { of land } \\
\text { covered } \\
\text { within area }\end{array}$ & $\begin{array}{l}\text { Number of times } \\
\text { vents have } \\
\text { erupted within } \\
\text { area (estimated) }\end{array}$ & $\begin{array}{l}\text { Number of } t \\
\text { lava flows ha } \\
\text { covered land } \\
\text { within area } \\
\text { (estimated) }\end{array}$ & imes \\
\hline A & 0 & 0 & 0 & 0 & & 0 \\
\hline B & 0 & 0 & 0 & 0 & Less than & 5 \\
\hline $\mathrm{C}$ & 0 & 0 & 0 & Less than & Less than & 5 \\
\hline D & 0 & 0 & 0 & 0 & More than & $10^{*}$ \\
\hline DE & 1 & 2 & 6 & More than 10 & More than & 10 \\
\hline $\mathrm{E}$ & 1 & $35^{*}$ & 15 & About $\quad 10$ & More than & $100^{*}$ \\
\hline $\mathrm{F}$ & 80 & More than 80 & 50 & About 2,000 & More than & 2,000 \\
\hline
\end{tabular}

*Most lava flows that entered areas $D$ and $E$ erupted from vents in area $F$. 


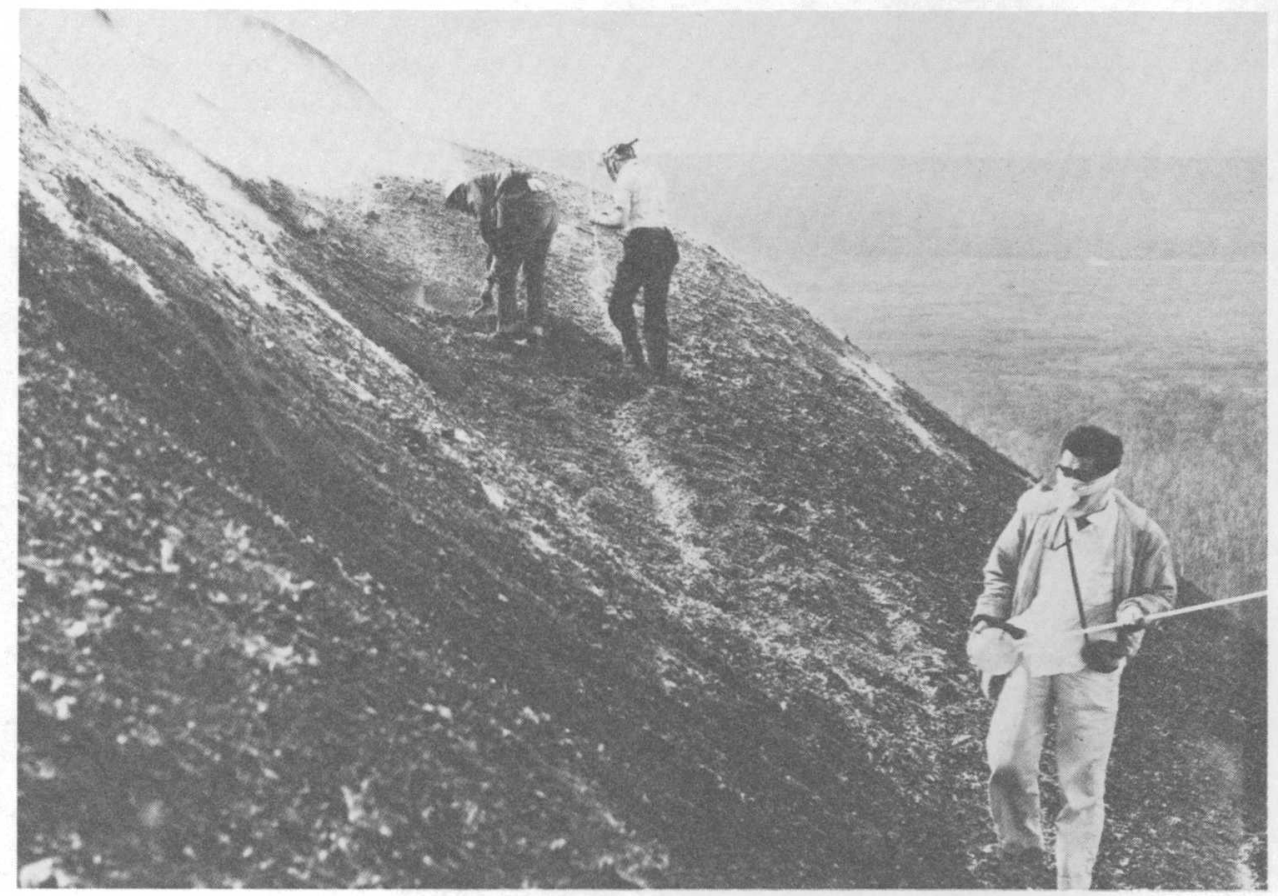

Geological Survey scientists examining hot cinder cone.

contrast, during the same period approximately 80 eruptions originated within area $F$, and some land within the area was buried by lava during each eruption. Lava has covered about half of area $\mathrm{F}$ during this period.

Records show that during each 20year period from 1830 to the present, between 25 and 75 square miles (65 and 195 square kilometres) of land have been covered by lava. This is approximately 1 to 3 percent of the region occupied by Kilauea and Mauna Loa. Area $\mathrm{F}$ occupies about one sixth of the area of Kilauea and Mauna Loa. Yet nearly 40 percent of all land covered by lava that erupted during historic time has been in areas designated F. This indicates that roughly 3 to 8 percent of the land in area $F$ has been buried during any given 20-year period. In this area of highest hazard, roughly 92 to 97 percent of the land remained free from lava burial during any specific 20-year period. Similarly, from about 0.5 to 3 percent of the land in area $E$ has been buried during various 20-year intervals, leaving 97 to 99.5 percent unaffected. Although it is not certain that this pattern will be maintained, past behavior still provides the best clue to future behavior.

10. Once an area has been covered by lava, is it safe from future burial?

No, although many people mistakenly thinkso. The entire island is made up of a succession of lava flows, attesting to repeated stacking of one flow over another throughout the volcanic history of the island. Some areas near Kilauea's summit and along the upper east rift zone have been covered repeatedly during the past few years. Recent flows across an area are no guarantee against future burial.

11. Are the risks uniform within a particular hazard area?

No, the risks may be quite variable throughout any hazard area, depending chiefly on the local topography and the distance from potential source vents. For example, the risk is greater on low ground than on higher ground in the same vicinity. Risks tend to be greater on steep slopes than on gentle slopes. And risks gradually decrease as the distance from eruptive vents increases. All of these factors vary throughout each of the designated hazard areas and, in particular, are important for those areas 
with historic activity. This variability shows that the classification of hazards is chiefly appropriate when applied to the area as a whole. Detailed studies of certain specific sites, however, might suggest a degree of risk either higher or lower than that designated for the area in which the site falls.

\section{How are the risks evaluated for land close to area boundaries?}

The risks can change either abruptly or gradually across area boundaries, depending upon the kind of boundary involved. Abrupt changes in risk occur across boundaries that are determined according to topographic features, such as the trough formed by the junction of the slopes of Mauna Loa and Mauna Kea. The trough itself may be threatened by lava flows from Mauna Loa, but risk from lava flows only a short distance up the adjoining flank of Mauna Kea is very low. Thus, a site only a short distance on one side of that boundary has an easily recognized and markedly different risk than a site a short distance on the other side of the same boundary.

Some area boundaries, however, have been designated according to judg- mental factors instead of specific topographic features. For example, the designation of the outer limits of rift zones is subject to considerable interpretation. The boundaries around areas somewhat protected from the direct paths of potential lava flows (such as areas marked D) are designated only by exercising a substantial amount of judgment. The approximate placement of such boundaries shows that the degree of risk applicable to two pieces of property close to each other, but on opposite sides of a judgmental boundary, cannot be considered to be significantly different. Boundaries designated as "judgmental" in figure 2 should be regarded as both approximate and gradational.

\section{How serious is the earthquake dan- ger on the island?}

Strong earthquakes have occurred in the past and can be expected in the future. The strongest earthquake in historic time occurred in 1868 and was centered along the island's south coast (fig. 3). This earthquake had a Richter magnitude of about $7 \frac{1}{2}$ and caused serious damage across the entire island. Recent quakes caused significant damage

Spatter fountain in eruption.

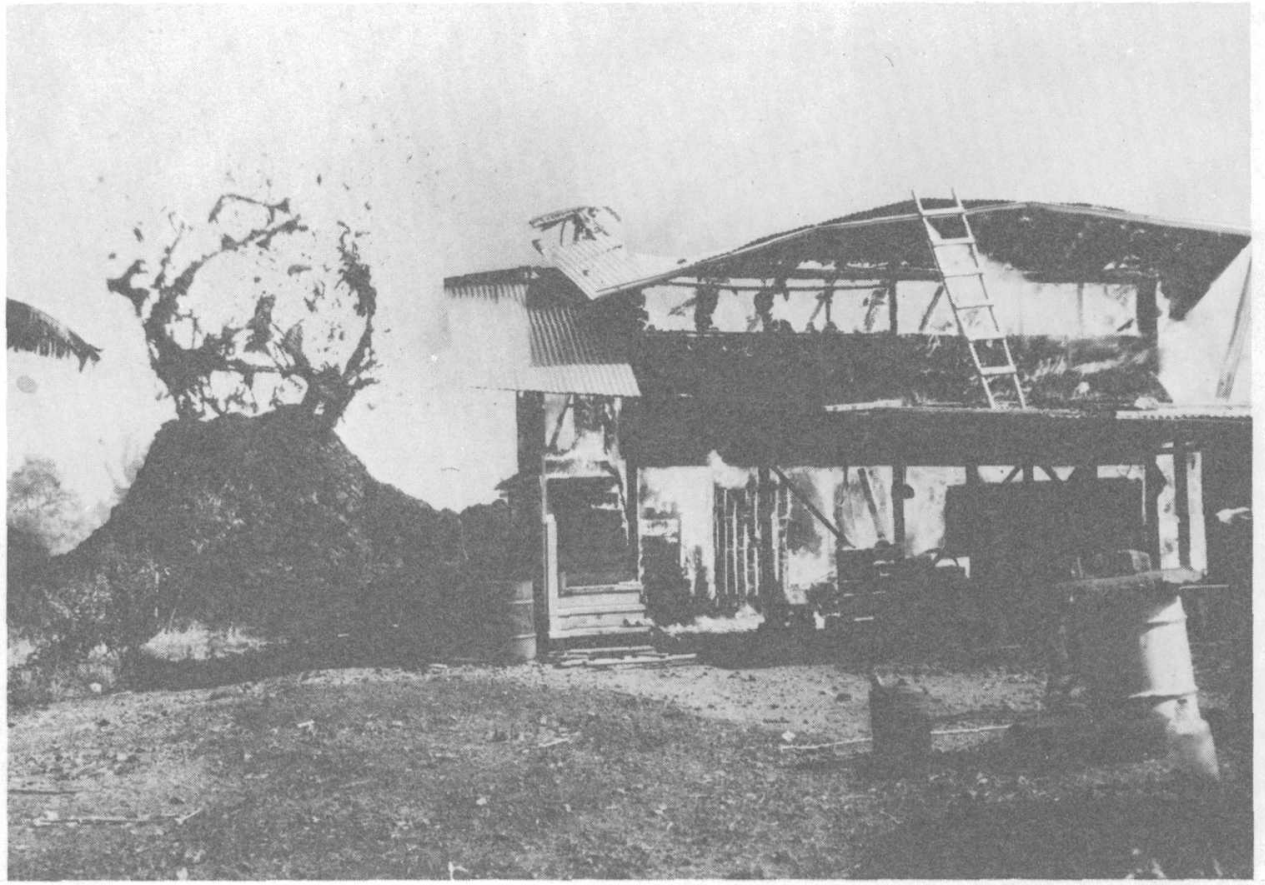


in 1951, 1973, and 1975. Figure 3 shows the approximate locations and the dates of some of the strongest historic earthquakes on and near the island. The frequency of these earthquakes and their widespread distribution show that the island faces an ever-present possibility of earthquakes strong enough to cause extensive damage.

Large earthquakes, unlike volcanic eruptions, are not confined to any particular part of the island. Furthermore, shaking may cause damage far from the point where the quake is centered. For this reason, it is not feasible to draw an "earthquake hazard map" of the island, such as figure 2 that illustrates the volcanic hazards. Risk of major damage from strong earthquakes is considered to be relatively high across the entire is- land. The risk is perhaps most severe in areas of steep and unstable slopes where landslides and rockfalls are likely to be induced by earthquakes. The risk from earthquakes on the island is comparable to that in many regions on the mainland United States and elsewhere that have high seismic hazards.

Danger from earthquakes can be minimized by careful site selection and proper earthquake-resistant design of man-made structures. Such matters as the angle and stability of slopes and the firmness of foundation sites vary widely from one locality to another. Competent evaluation of individual sites during land-use planning can do much to reduce earthquake risks. Local officials have the responsibility of maintaining proper standards of site selection and earthquake-resistant construction.

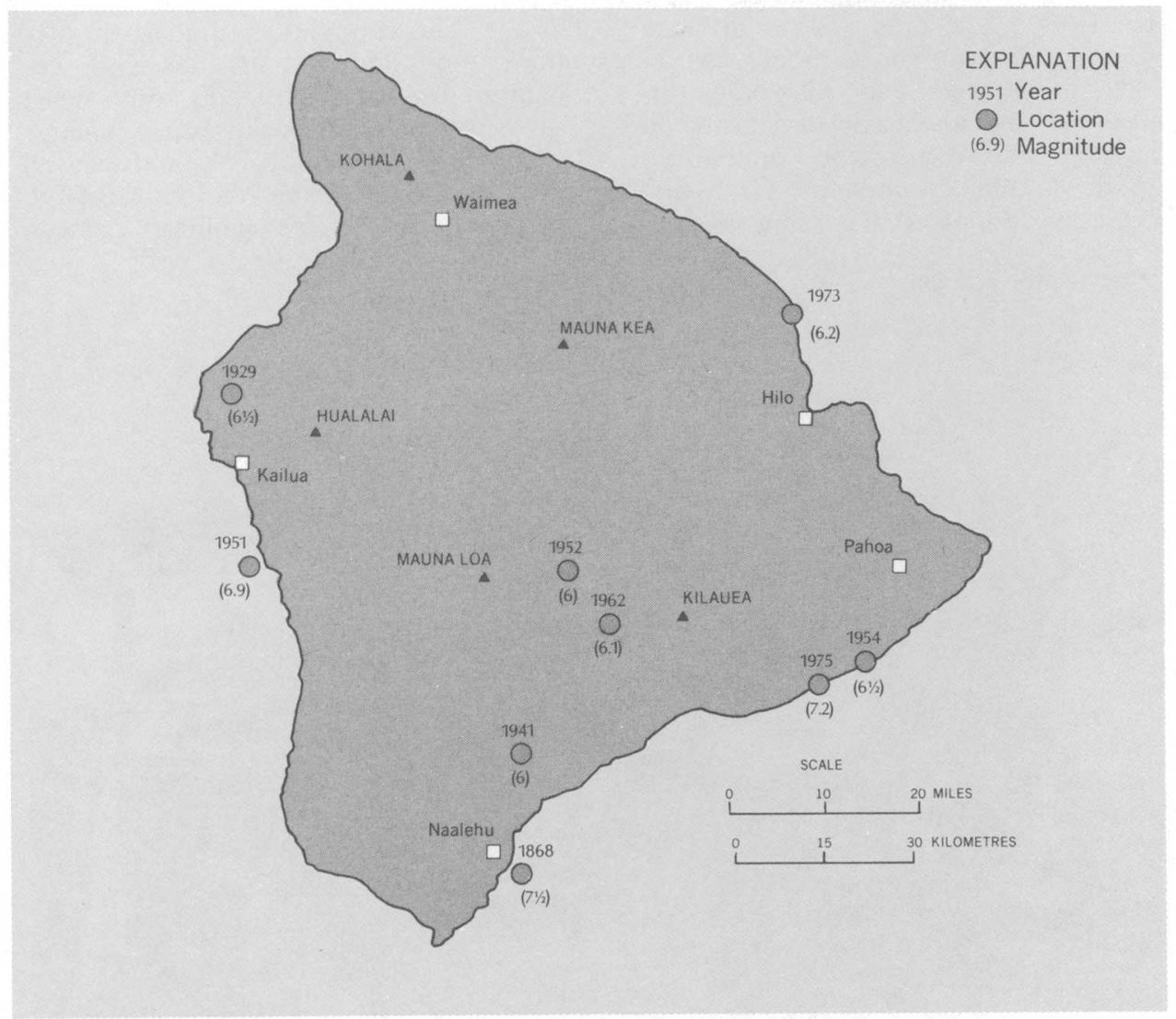

Figure 3.- Location of points of origin of major historic Hawaiian earthquakes whose magnitude exceeded 6. Locations and magnitudes for earthquakes prior to 1960 are highly approximate because instrumental data are sparse, therefore fractions are used. 


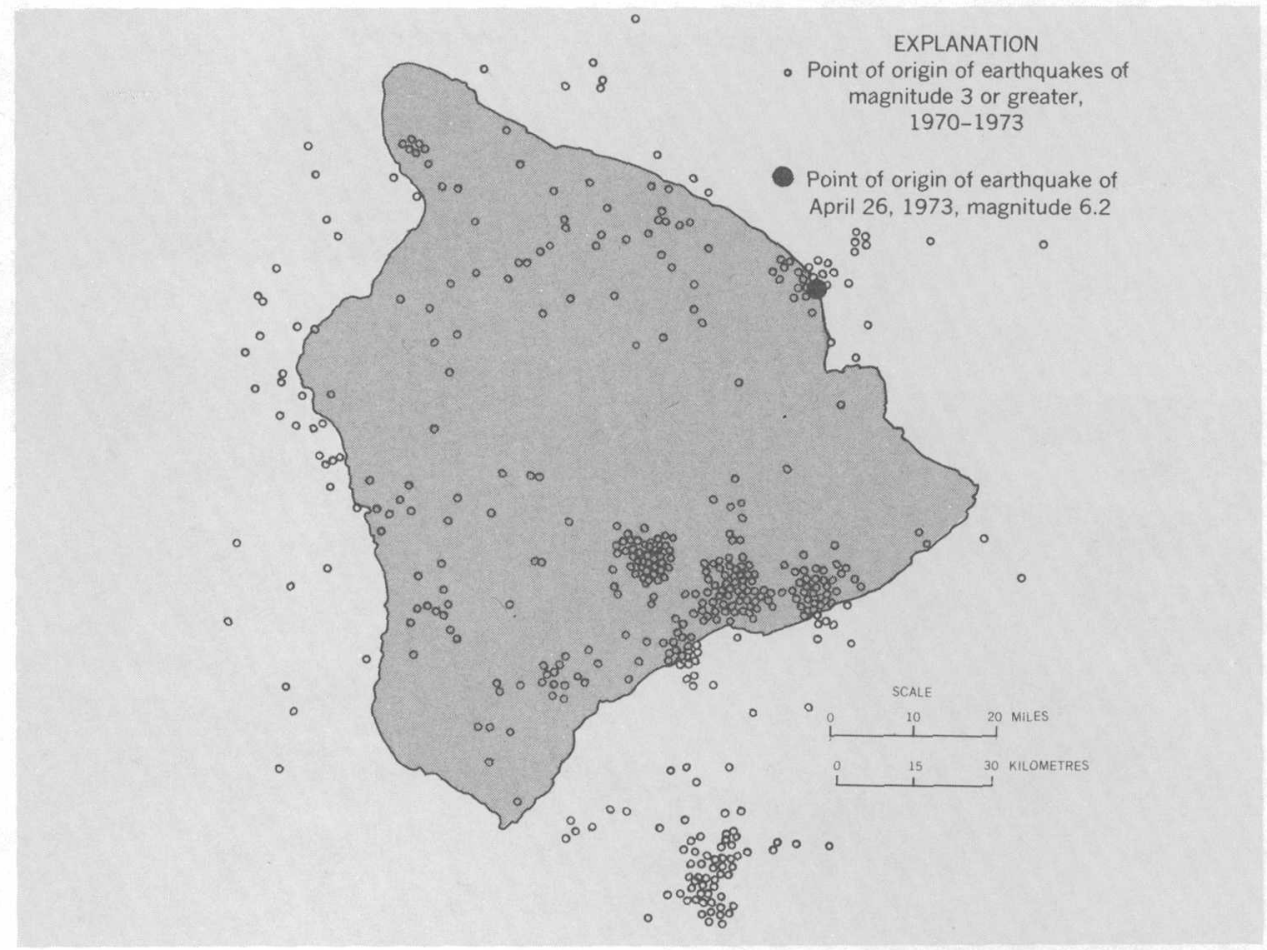

Figure 4.-Points of origin of earthquakes of magnitude 3 or greater on or near Hawaii from 1970 to 1973.

\section{Aren't many Hawaiian earthquakes concentrated in certain areas?}

Yes. In recent years the greatest number of earthquakes on the island have occurred on or near Kilauea, but earthquakes also tend to be concentrated in other specific areas. An example of how earthquakes are concentrated is the map of figure 4, which shows the distribution of earthquakes of larger than magnitude 3 that occurred from 1970 to 1973 . Maps for other periods of time may show different distributions. Most of these earthquakes are much smaller than the major earthquakes previously discussed, and few caused damage. Of the earthquakes shown in figure 4, only the one of April 26,1973 , caused any significant damage. However, hundreds of those shown in the figure were strong enough to be felt. Thousands more, not shown on this map, were so small that they were detected only by sensitive instruments. Quakes smaller than about magnitude 5, even those that can be felt, do not pose a substantial hazard to life and property. When they occur in swarms, however, such as those on Kilauea's southwest rift zone in December 1971 and January 1975, the earthquakes can be conspicuous, annoying, and sometimes frightening.

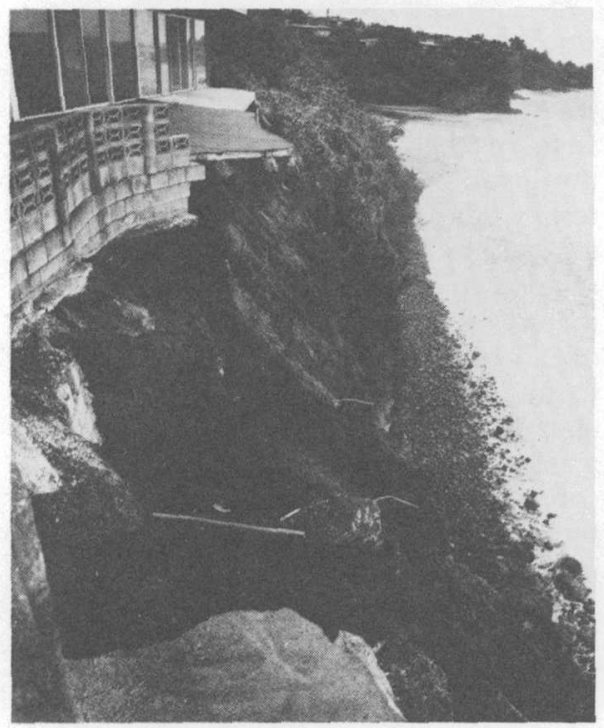

Ground failure caused by an earthquake. 


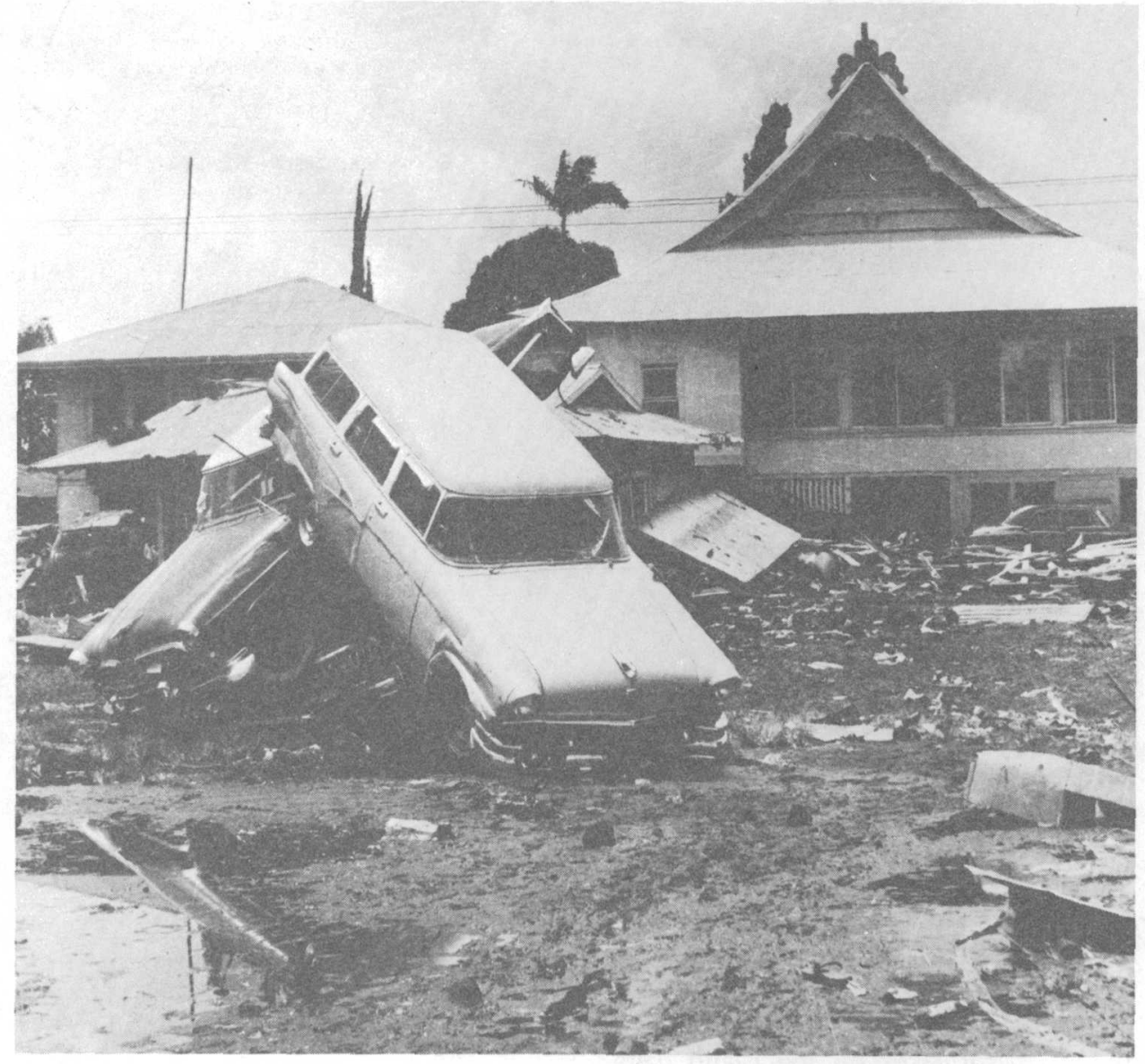

Damage caused by a tsunami.

\section{What is a tsunami?}

A tsunami is a giant wave or series of waves produced by a large-scale disturbance of the ocean floor. "Tsunami" is the Japanese name for these waves; the term "tidal wave" is also used, but it is misleading because the waves have no relation to tides. Most tsunamis are generated by the sudden movement of the ocean floor along a fault-a submarine earthquake. Others may be caused by abrupt subsidence of the ocean floor or a submarine volcanic eruption. Tsunamis spread outward in all directions from their source. In the open ocean they may travel for thousands of miles at speeds of several hundred miles per hour.

\section{How does a tsunami do damage?}

When a tsunami reaches some coastlines, it may rush ashore at high speeds, flooding and smashing all in its path. While at sea, a tsunami is scarcely noticeable. As the wave enters shallow water or is funnelled into a bay, it can build to great heights. Some have been recorded at more than 100 feet $(30$ metres) above normal sea level. Reaching a shoreline, a tsunami advances inland at velocities of 30 to 60 miles (50 to $100 \mathrm{~km}$ ) per hour, endangering life and destroying property. They can be powerful enough to smash buildings and toss anchored ships ashore. As they recede, people, animals, and property may be swept into the sea. A tsunami may include several waves, separated by intervals of 5 to 40 minutes. Areas that escape early waves may be damaged by those later in the series. 


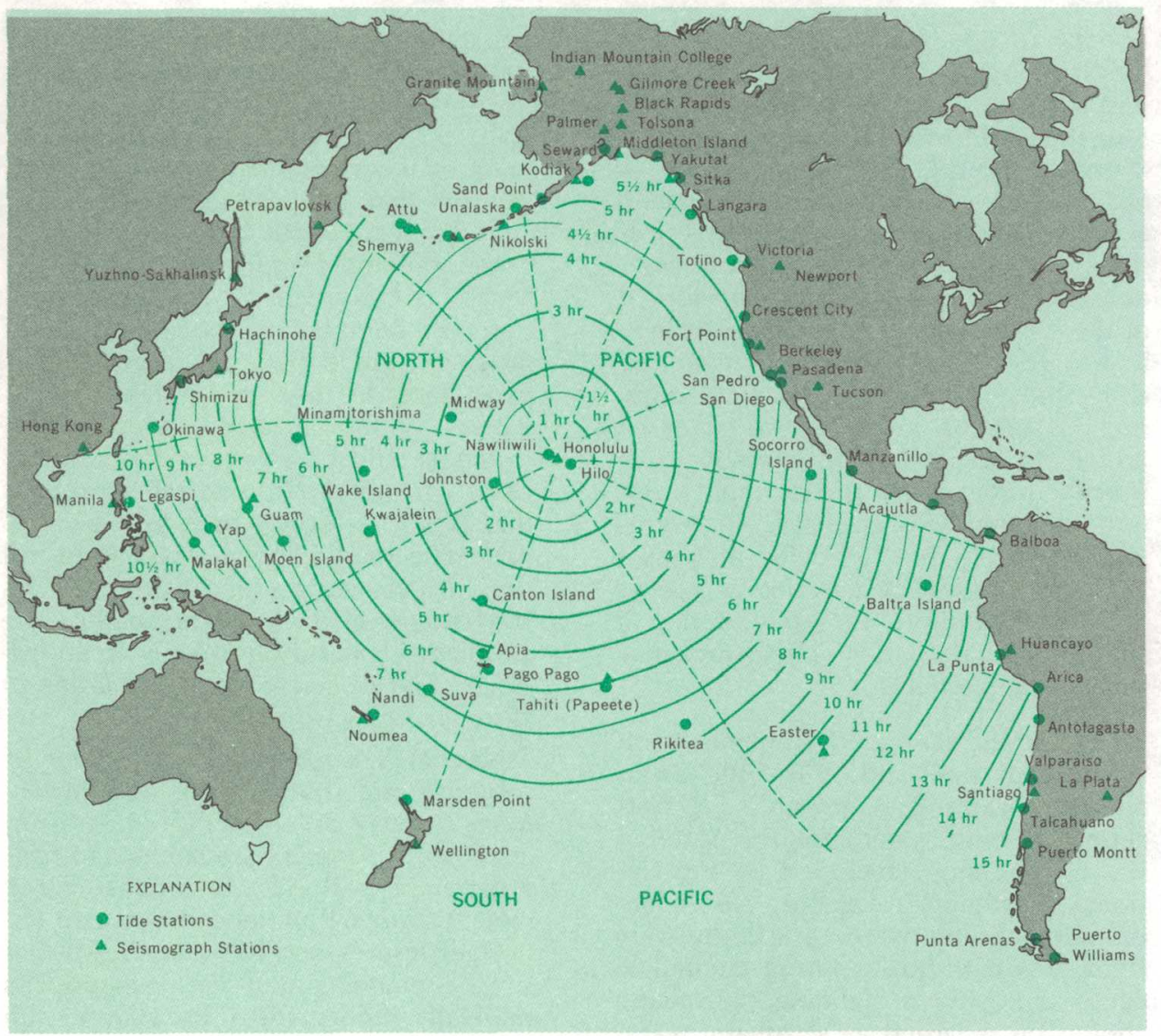

Figure 5.- Tsunami Warning System showing reporting stations and tsunami travel times to Honolulu. Concentric circles radiating from Hawaii like a gigantic spider web show seismic sea wave travel times to Honolulu. Reporting stations in the tsunami warning system are encompassed by a great ring bounded by such diverse locales as Alaska, China, and Chile.

\section{How serious is the tsunami threat to Hawaii?}

Hawaii is vulnerable to destructive tsunamis of distant origin, as well as less frequent ones that originate close to the island. The Pacific Ocean is ringed by a belt of active faults that may cause ocean bottom displacements, but, fortunately, few circumpacific earthquakes generate tsunamis. Since the early 19th century, about 40 tsunamis have been large enough to be reported in Hawaii. Of these, seven caused severe damage; five of the seven were generated by earthquakes thousands of miles away, such as the 1946 tsunami that originated in the Aleutian Islands and the 1960 tsunami that originated near Chile. Each killed many people and caused millions of dollars worth of damage. The tsunamis of 1868 and 1975 were of local origin. The tsunami of 1868 , the most severe, devastated the entire southern coast of the island, killing about 80 people and destroying several villages. The tsunami of 1975 claimed two lives, and although it caused widespread damage, its strongest effects were in uninhabited areas. Tsunamis are a great, though infrequent, danger to both people and property in coastal regions of Hawaii, perhaps greater than that posed by either volcanoes or earthquakes.

\section{Are advance warnings of approach- ing tsunamis possible?}

Yes. Following the very destructive tsunami in 1946, a warning system was developed by the U.S. Coast and Geodetic Survey (fig. 5). The system is now administered by the National Weather 
Service of the National Oceanic and Atmospheric Administration (NOAA) and is closely tied to the International Tsunami Information Center. When a strong earthquake is centered under or near the Pacific Ocean, a "tsunami watch" is issued advising that a tsunami is possible. If large waves are subsequently detected at tide stations near the source of the earthquake, a "tsunami warning" is issued. For any tsunami generated along the margin of the Pacific Ocean, such a warning gives several hours of notice to Hawaii. This permits safe evacuation of people and movable property from low-lying coastal areas. Warnings now include the advice that most tsunamis consist of a series of waves that may continue to arrive during a span of several hours; the first wave may not be the strongest.

For locally generated tsunamis, such as those of 1868 and 1975 , little or no advance warning is possible. A fastacting warning system for the State of Hawaii is being developed by the $\mathrm{Na}$ tional Weather Service, but, even when operational, the warning will be very brief. Any earthquake strong enough to cause difficulty in standing or walking should be regarded as a tsunami warning by people in coastal areas. Longterm protection from locally generated tsunamis will be aided by careful planning of the location of structures and developments, particularly for activities associated with high concentrations of people.

\section{What do volcanic and other natural hazards mean for people who live, work, and visit on Hawaii?}

It is important for people to be aware of the hazards and also to realize that it is possible to plan and carry out their affairs in ways that can minimize the effects of the hazards. Often, sensationalistic publicity has drastically overstated the potential hazards-doomsdaytype statements are misleading, irresponsible, and damaging. On the other hand, complacency is equally undesirable and may court disaster. The areas that are relatively susceptible to natural hazards should be sensibly recognized. Policies on land use should be adopted that in- sure that new developments are planned for minimum risk to life and property. Obviously, for some areas, it is impossible to avoid some degree of risk. In some places the degree of risk may indicate that low-density development requiring few people and only light construction is more appropriate than highdensity development. Individuals and firms contemplating the purchase of property should have full access to reliable facts so they can understand the nature of the hazards problem. Taxpayers should be aware of the possible costs of publicly funded relief projects that assist affected property owners. Adequate public knowledge should not only dispel over-reaction to the hazards but should also eliminate apathy. The problems should be openly acknowledged and discussed and not hidden or dismissed by wishful thinking.

Natural hazards and the problem of response are not unique to Hawaii. Many densely developed areas on mainland North America are subject to hazards such as floods, earthquakes, and violent storms. Experience has taught important lessons and has also shown that proper planning and construction can markedly reduce the risks. Hawaii, still relatively undeveloped, has the opportunity to make wise choices on patterns of land use that will minimize the effects of natural hazards and protect the livelihood and welfare of residents and visitors.

20. What are other sources of information about volcanoes, earthquakes, and tsunamis of Hawaii?

The following selected references describe these natural hazards in more detail than is possible in this short booklet. Additional information on tsunamis may be obtained by writing to the International Tsunami Information Center, P.O. Box 3650, Honolulu, Hawaii 96811.

(From material provided by D. W. Peterson and D. R. Mullineaux)

\section{Photo Credits}

Cover. Right center, US. Army Corps of Engineers; bottom, Rev. S. N. McCain, Jr. Others: Honolulu Advertiser, Hawaii Tribune-Herald, Larry S. Kadooka 


\section{References}

Ayre, R. S., 1975, Earthquake and Tsunami Hazards in the United States-a Research Assessment: Univ. of Colorado, Inst. of Behavioral Science, Program on Technology, Environment and Man, Monograph 005, 150 p.

Bolt, B.A., and others, 1975, Geological Hazards: New York, Springer-Verlag, $328 \mathrm{p}$.

Coffman, J. L., and von Hake, C. A., 1973, Earthquake History of the United States: U.S. Dept. of Commerce, Nat'l. Oceanic and Atmospheric Admin. Publication 41-1, $208 \mathrm{p}$.

Macdonald, G. A., and Abbott, A. T., 1970, Volcanoes in the Sea: Honolulu, Univ. of Hawaii Press, 441 p.

Macdonald, G. A., and Hubbard, D. H., 1973, Volcanoes of the National Parks in Hawaii (6th edition): Hawaii Nat. Hist. Assn., 56 p.
Macdonald, G. A., 1972, Volcanoes: Englewood Cliffs, N. J., Prentice-Hall, Inc., $510 \mathrm{p}$.

Mullineaux, D. R., and Peterson, D. W., 1974, Volcanic Hazards on the Island of Hawaii: U.S. Geol. Survey OpenFile Rept. 74-239, 61 p. (Out of print, but available for consultation in certain U.S. Geol. Survey Offices and in Hawaiian libraries.)

Richter, C. F., 1958, Elementary Seismology: San Francisco, W. H. Freeman, $768 \mathrm{p}$.

Stearns, H. T., 1966, Geology of the State of Hawaii: Palo Alto, Calif., Pacific Books, $266 \mathrm{p}$.

Warrick, R. A., 1975, Volcano Hazards in the United States-a Research Assessment: Univ. of Colorado, Inst. of Behavioral Science, Program on Technology, Environment and Man, Monograph 012, $144 \mathrm{p}$.

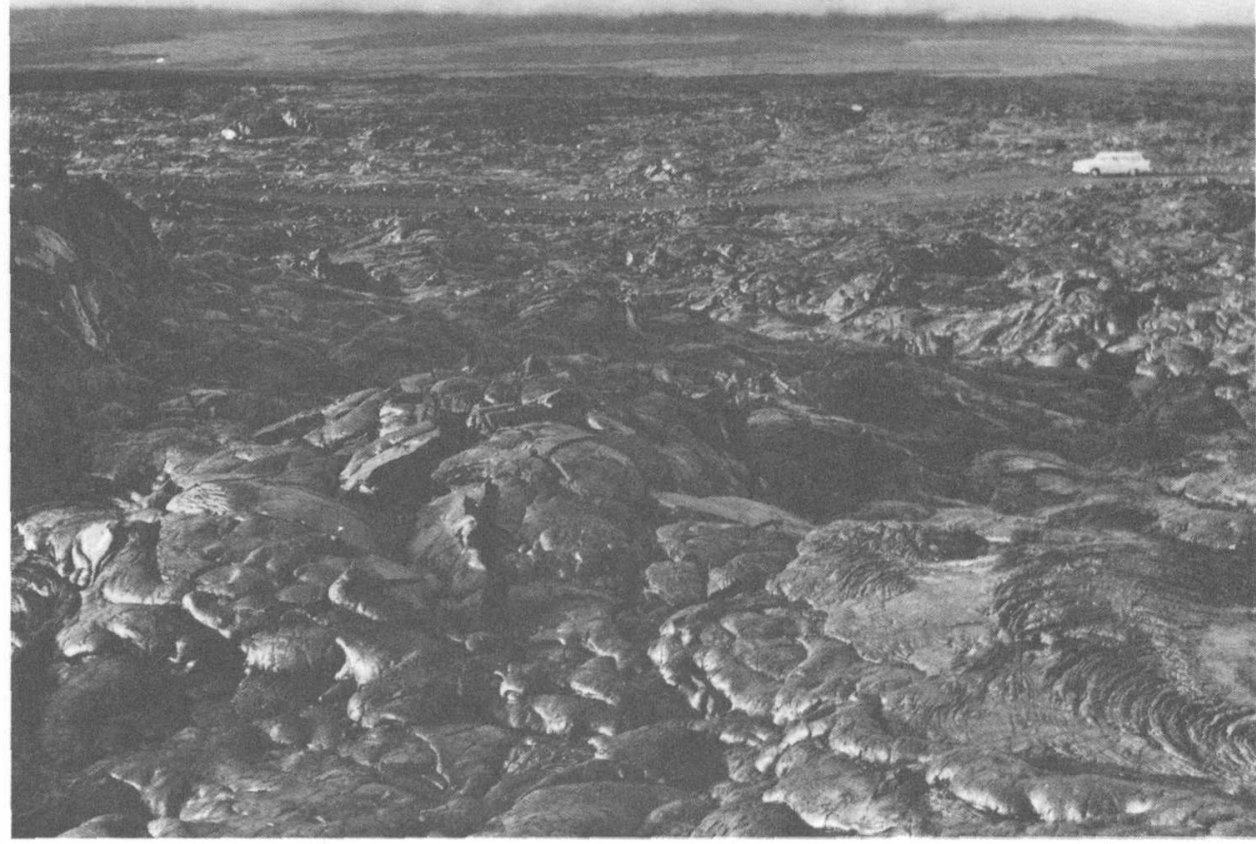


As the Nation's principal conservation agency, the Department of the Interior has responsibility for most of our nationally owned public lands and natural resources. This includes fostering the wisest use of our land and water resources, protecting our fish and wildlife, preserving the environmental and cultural values of our national parks and historical places, and providing for the enjoyment of life through outdoor recreation. The Department assesses our energy and mineral resources and works to assure that their development is in the best interests of all our people. The Department also has a major responsibility for American Indian reservation communities and for people who live in Island Territories under U.S. administration.

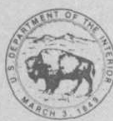

Cecil D Andrus, Secretary

U.S. Department of the Interior

V.E. McKelvey, Director Geological Survey

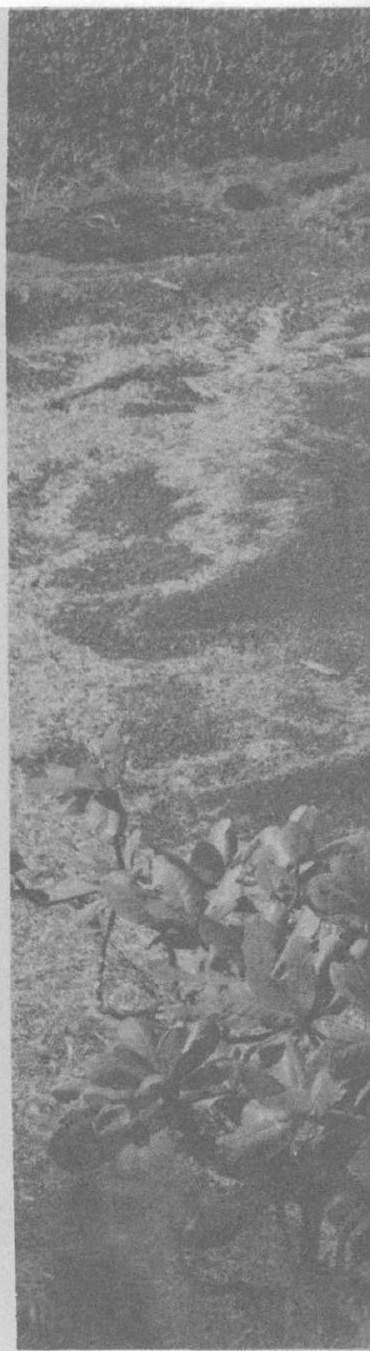

